XLIX.-On new Land-Shells from Darjiling, with a series of new Indian Species of Achatina. Described by W. H. Benson, Esq.

\title{
Diplommatina Blanfordiana, B.
}

Testa dextrorsa, foveato-rimata, ovato-acuminata, confertim arcuatocostulata, albida, spira ovato-pyramidata, superne attenuata, apice acutiusculo, sutura impressa; anfractibus $7 \frac{1}{2}$ convexis, antepenultimo majusculo tumido, ultimo antice ascendente; apertura subverticali, late auriculari, plica columellari valida nutante munita, peristomate expanso, extus varice retrorelicta remotiuscula valida aucto, infra ad sinistram subangulato, marginibus callo parietali crasso expanso appresso junctis, columellari leviter sinuato. Operc. $\longrightarrow$ ?

Long. $4 \frac{1}{2}$, diam. $2 \frac{1}{3}$ mill.

Habitat prope Darjiling. Teste W. T. Blanford.

Independently of its smaller size and stronger costulation, this shell is distinguished from $D$. pachycheilus by its foveate rimation behind the thin columellar lip, and by the retrorelict variciform second peristome, which is remote in its course, on the right side, from the thin actual peristome, but joins it below the umbilical cavity. In D. pachycheilus the peristome is thickened and bifurcate at the insertion of the outer lip, and there is no remote varix; while the incrassate columellar lip is reflected over the rimation, and entirely conceals it. The last whorl ascends more conspicuously in front than in D. pachycheilus, although it rises considerably also in that shell-a feature which I omitted in the description given in the 'Annals' for 1857. The costulation of $D$. pachycheilus is very variable; in some specimens it disappears on the lower whorls, in others on the upper ones only; occasionally it pervades the surface.

The following characters may be added to those already given of $D$, pachycheilus :-

Anfractu ultimo antice ascendente; peristomate superne ad angulum bifurcato, margine columellari externe callo expanso irregulari appresso, periomphalum obtegente, munito.

It is found among dead leaves with $D$. Blanfordiana.

\section{Ennea stenopylis, B.}

Testa longe curvato-rimata, cylindraceo-ovata, arcuatim costulata, sub epidermide cereo-cornea albida ; apice conoideo-obtuso, sutura impressa; anfractibus 6 angustis, convexiusculis, ultimo minore compresso, antice leviter ascendente, latere dextro antice substrangulato, valde scrobiculato, basi anguste compressa ; apertura verticali, subaxiali, triangulari-obovata, subcordiformi, $\frac{1}{3}$ testæ superante, peristomate undique expanso calloso reflexiusculo, margine dextrali superne profunde sinuato, plica angulari parietali valida, superne sub-bicruri, margines peristomatis jungente, subtus lamel- 
liformi profunde intrante, denteque palatali unica intus longe et contigue concurrentibus, aperturam coarctatam inæqualiter oblique dividentibus, aream minorem quasi perforatam prope sinum dextralem, ab area sinistra majore ovato-oblonga, secernentibus.

Long. $3 \frac{1}{2}$, diam. $1 \frac{1}{2}$ mill.

Habitat in vallibus Rungnu et Rimmau (alt. 4000 ped.) prope Darjiling. Detexit W. T. Blanford.

Although differing so much in form from Ennea vara, B., of the Khasia Hills, this shell is nearly allied to it in the formation and dentation of the aperture; the characters are, however, on a more exaggerated scale. The Cape Pupa Layardi, B., in its parietal and upper palatal plicæ, approaches the structure observable in $E$. stenopylis, in which the plaits meet so closely during their descent as to leave a scarcely visible line of separation, cutting off the sinus at the upper part of the dextral margin so completely as to present an analogy to the basal canal of Cataulus. Like $E$. vara, the aperture is deficient in columellar folds. The parietal callus is a modified representation of that of the South Indian E. Pirriei, Pfr.

\section{Achatina Hastula, B.}

Testa turrito-subulata, tenui, oblique capillaceo-striata, fusco-cornea, nitidula; spira subulata, apice obtuso, sutura profundiuscula; anfractibus 9 , primis convexis; postremis convexiusculis, ultimo $\frac{2}{7}$ testæ vix attingente; apertura vix obliqua, ovato-elliptica, peristomatis marginibus callo tenui junctis, dextrali recto acuto, columellari arcuato calloso albido, basi oblique truncata.

Long. $12 \frac{1}{2}$, diam. $3 \frac{1}{2}$ mill.; long. apert. $3 \frac{1}{2}$ mill.

Habitat ad Pankabari, prope Darjiling, raro. Teste W. T. Blanford.

Of a more slender form than the large Ach.tenuispira, B., the whorls increasing very gradually, and not attenuate towards the upper part of the spire as in that species.

\section{Achatina Orobia, B.}

Testa ovato-oblonga, solidiuscula, lævigata, leviter striata, striis nonnullis remotiusculis profunde impressis sculpta, nitida, olivaceocornea ; spira convexe pyramidata, apice obtuso, sutura impressa; anfractibus $6 \frac{1}{2}-7 \frac{1}{2}$ convexiusculis, ad humerum angulatis, crenulatis, ultimo $\frac{1}{3}$ testæ superante ; apertura verticali semiovali, columella valde arcuata, callosa, basi oblique truncata, peristomate recto, crassiusculo, obtuso.

Long. 11, diam. 5 mill.; apert. 4 mill. longa, 3 lata.

Habitat ad Sinchul et Darjiling (alt. ped. 8500 et 7000). Teste W. T. Blanford.

Distinguished from the larger Khasia species, A. crassilabris, B., by its peculiar sculpture, and by the formation of the whorls below the suture. 
The following shells are added to complete the history of the known Indian species of Achatina :-

\section{Achatina pralustris, B.}

Testa ovato-oblonga, pertenui, fragili, irregulariter plicato-striata, nitente, pallide luteo-cornea ; spira pyramidata, apice obtuso, sutura profundiuscula, subcrenulata ; anfractibus $8 \frac{1}{2}$ convexiusculis, superne prope suturam tumidiusculis, ultimo $\frac{1}{3}$ testæ superante, subinflato; apertura verticali, semiovali, latiuscula, columella subrecta, vix curvata, basi oblique truncata, peristomate recto, acuto. Long. 33, diam. 17 mill.; apert. 15 mill. longa, 9 lata.

Habitat in provincia Orissa prope Midnapore, Balasore, et Cuttack. Teste W. Theobald.

This is the largest known Indian form of the type to which the Cingalese and Nilgherry shell, Ach. Ceylanica, Pfr., belongs. It was found by Mr. Theobald in Mangoe topes, both in the hills and plains.

\section{Achatina Chessoni, B.}

Testa ovato-turrita, superne attenuata, scabre plicato-striata, striis minutissimis confertis obsoletis spiralibus decussata, fulvo-cornea, vel purpureo-fusca, translucente, nitidula; spira turrita, apicem versus obtusiusculum attenuata, sutura impressa, crenulata; anfractibus $11 \frac{1}{2}$ convexiusculis, ultimo $\frac{1}{3}$ testæ superante inflatiusculo; apertura subverticali, semiovali, latiuscula, columella subrecta, albido-callosa, basi vix oblique truncata, peristomate recto, tenui.

Long. 37, diam. 15 mill.; apert. 14 mill. longa, 8 lata.

Habitat in montibus Mahabaleshwar. Detexit J. Chesson.

There is also a more slender variety, 33 mill. in length by 12 in breadth.

This fine shell, the largest of the forms intermediate between Ach. pralustris of the eastern coast of the Peninsula and the north-eastern $A$. Cassiaca, was found on the high mountain group overlooking the western coast of the Indian Peninsula, south of Bombay, by Mr. J. Chesson. It was accompanied by the following species.

\section{Achatina notigena, $\mathrm{B}$.}

Testa elongato-conica, superne attenuata, tenui, subcostulato-striata, fulvo-cornea, nitida, pellucida; spira turrita, superne attenuata, apice obtuso, sutura impressa, irregulariter crenulata ; anfractibus 9-10 convexiusculis, ultimo $\frac{1}{3}$ testæ non attingente ; apertura subverticali, anguste semiovali, columella vix arcuata, subverticali, basi suboblique truncata, peristomate recto, tenui, marginibus callo tenui junctis.

Long. 20, diam. 7 mill.; apert. 6 mill. longa, vix 4 lata.

Var. inflatior, ovato-turrita, long. 22 , diam. 8 mill.

Habitat in montibus Mahabaleshwar cum præcedente, teste J. Chesson; necnon prope Bombay, W. Theobald.

This shell has relations to Ach. Chessoni in the attenuation of 
the spire towards the summit,-a feature observable also in the north-eastern A. tenuispira. It differs in form, size, proportions, \&c. In one specimen from Bombay, the attenuation of the spire is less conspicuous.

\section{Achatina Sarissa, B.}

Testa elongato-conica, tenui, lævigata, striatula, anfractibus ultimis sub lente confertim obsolete decussatis, nitidissima, olivaceo-cornea ; spira elongato-pyramidata, apice obtuso, sutura impressa ; anfractibus $9 \frac{1}{2}$ convexiusculis, ultimo $\frac{2}{7}$ testæ superante ; apertura subverticali, ovato-elliptica, columella obliqua, leviter arcuata, albido-callosa, basi oblique truncata, peristomate recto, tenui.

Long. 16, diam. $5 \frac{1}{2}$ mill.; apert. 5 mill. longa, $3 \frac{1}{2}$ lata.

Habitat prope Comercolly, Bengaliæ, ad ripas fluminis Gangis. Detexit Dr. Theodore Cantor.

I am indebted to Dr. Cantor for this interesting addition to the few species which inhabit the plains of Lower Bengal.

\section{Achatina Pyramis, B.}

Testa oblongo-turrita, solidula, lævigata, striatula, nitida, luteo-cornea; spira turrita, lateribus convexiusculis, apice obtusiusculo, sutura impressa; anfractibus 8 , convexiusculis, ultimo $\frac{1}{3}$ testæ æquante, antice obsolete plicato; apertura subverticali, ellipticosemiovali, columella arcuata, callosa, basi oblique truncata, peristomate recto obtuso, intus albido-labiato.

Long. 15, diam. 6 mill.; apert. 5 mill. longa, $2 \frac{1}{2}$ lata.

Habitat ad Teria Ghât Montium Khasia. Detexit W. Theobald.

Allied to the smaller Ach crassula, B., from Darjiling, but distinguished from it by its colour, smoother sculpture, more convex and numerous whorls, by the characters of the peristome, and by the convex and not planate sides of the spire.

A large variety of Ach. crassula, collected by Mr. W. T. Blanford near Darjiling, is 12 mill. in length by $5 \frac{1}{2}$ in breadth, and, like the type, possesses only seven whorls.

\section{Achatina Scrutillus, B.}

Testa oblonga, solidiuscula, lævigata, subremote striatula, nitidula, fulvo-cornea; spira ovato-oblonga, apice obtuso, sutura impressa ; anfractibus $5 \frac{1}{2}$ convexiusculis, ultimo $\frac{1}{3}$ testæ superante; apertura verticali, ovato-elliptica, columella valde arcuata, basi subito et profunde truncata, peristomate recto, obtuso, marginibus callo crassiusculo junctis.

Long. 6 mill., diam. $2 \frac{2}{3}$; long. apert. $2 \frac{1}{2}$ mill.

Habitat in Provincia Orissa (Cuttack), necnon in valle superiore fluminis Nerbuddæ, Indiæ Centralis. Detexit W. Theobald.

This little species may be at once known on comparison with the Bengal Ach. Gemma, B., which is ordinarily of the same 
size, by its less rapidly decreasing spire, solidity, and colour; and from the paler $A$. Frumentum, Reeve, which is probably only a local variety of Ach. Gemma, by the two first-mentioned characters.

I have a large variety of $A$. Gemma, collected by Dr. Bacon, which attains a length of 8 mill. by $3 \frac{1}{2}$ in breadth.

A single specimen of Achatina Amentum, B., 24 mill. in length, and with nine whorls, was found by Mr. W. Theobald in the Valley of the Upper Nerbudda. It is not in good condition, the upper whorls being bleached; but the form and sculpture leave little room for doubt as to its identity with the Calcutta species, which is exceedingly rare, three specimens only having been taken by me in a living state twenty-five years ago. They were under a felled palm-tree (Borassus flabelliformis) on the Howrah bank of the river, between the Bishop's College and the Botanic Gardens. The late Dr. Pearson believed that he had found the young shell, 2 lines in length, at Alipore, near Calcutta. Search should be made for the species within the cool and moist bases of the fronds of Palmyra, Cocoa-nut, and other Palms.

An undescribed Achatina occurs in the Mahabaleshwar Hills, nearly related to $A$. Ceylanica, Pfr., but differing from it in its acuninate summit. The single specimen found by Lieut. Arthur E. Benson is in too decayed a state for description. Its length is 15 mill., and diameter 8 mill. Another smaller shell, of a similar type, and with the summit less pointed, was taken by Mr. Theobald at Teria Ghât, in the Khasia Hills. It is probably a new species; and the examination of a perfect shell is desirable. With it Mr. Theobald found a small solid form, in a bleached condition, which appears to be a dwarf variety of $A$. crassilabris, B., 11 mill. in length by 6 in diameter.

A weathered and imperfect Achatina, sent by Mr. Theobald from Orissa, resembles the Nilgherry $A$. Oreas, B., when of immature growth. I have a pale variety of $A$. Oreas from M. Petit, which was stated to have been received from Bombay. It accords with the mountain type in all but colour.

In Burmah Mr. Theobald got a variety of A. tenuispira on the banks of the Irawady, and at Phie Thán the young of a reversed species, which is doubtless new. An adult specimen is a desideratum. The young presents from three to four smooth hyaline whorls, with a distinct truncation at the base. The shell figured in 'Conchologia Iconica' as Bulimus Sikkimensis, Reeve, proves to be an extremely young specimen of a fine Spiraxis, of which an example with seven whorls, obtained at Darjiling by $\mathrm{Mr}$. W. T. Blanford, measures 27 mill. in length by nearly 10 in diameter. 
Mr. W. H. Benson on new Indian Species of Achatina. 465

The following list exhibits the names and localities of all the Continental-Indian species of Achatina which have hitherto been described:-

A. tenuispira, B. Khasia Hills, Darjiling, and Burmah,

- Cassiaca, B. Khasia Hills.

- crassilabris, B. „,

- Pyramis, B.

- crassula, B. Darjiling.

- Hastula, B. "

- Orobia, B.

- Amentum, B. Lower Bengal and Nerbudda.

- Sarissa, B.

- Gemma, B.

"

- Frumentum, Reeve. ",

- prelustris, B. Orissa.

(Var. of Gemma.)

- Scrutillus, B. Orissa and Nerbudda.

- Chessoni, B. Mahabaleshwar Hills.

- notigena, B. Mahabaleshwar Hills and Bombay.

- Oreas, B. Nilgherries and Bombay.

- Perrotteti, Pfr. (Nilagirica, B.). Nilgherries.

- Jerdoni, B. Nilgherries.

- Ceylanica, Pfr. (Orophila, B.) Nilgherries.

- Bensoniana, Pfr. Nilgherries.

- Shiplayi, Pfr.

- corrosula, Pfr.

- Balanus, B. Banks of Jumna.

Cheltenham, April 28, 1860.

Supplementary Notice, containing Descriptions of two new Species of Achatina from the Nilgherries.

The two following species, which should have been included in my paper on Indian Achatina, were inadvertently omitted:Achatina Botellus, B.

Testa oblonga, solidiuscula, lævigata, leviter striatula, sub lente indistincte confertim, spiraliter, minutissime acuducta, polita, fulvocastanea; spira ovato-oblonga, apice valde obtuso, sutura impressa, leviter crenulata; anfractibus 7 convexiusculis, ultimo vix latiore; apertura subobliqua, semiovali, intus albida, columella valde arcuata, albido-callosa, basi subverticaliter truncata, peristomate recto, marginibus callo tenui junctis, dextrali latiusculo, planato, non incrassato.

Long. 18, diam. $7 \frac{1}{2}$ mill.; apert. 7 mill. longa, $3 \frac{2}{3}$ lata. Habitat in montibus Nilgherries. Detexit T. Jerdon.

A single specimen of this very distinct species was received from Dr. Jerdon with the following.

Ann.\& Mag. N. Hist. Ser. 3. Vol. v. 


\section{Achatina Facula, B.}

Testa turrito-ovata, tenui, lævigata, irregulariter striatula, translucente, nitida, pallide fulvo-cornea; spira turrito-conica, apice obtuso, sutura profundiuscula, irregulariter vix crenulata; anfractibus $7 \frac{1}{2}$, subconvexis, ultimo $\frac{2}{5}$ testæ vix attingente, antice leviter remote plicato-striato; apertura subverticali, semiovali, columella breviter valde arcuata, callosa, basi oblique truncata, peristomate recto, tenui, marginibus callo tenui junctis.

Long. 18, diam. 8 mill.; apert. 7 mill. longa, $4 \frac{1}{2}$ lata.

Syn. Ach. Perrotteti, Conch. Icon. pl. 21. f. 102, nec Pfr,

Habitat in montibus Nilgherries, T. Jerdon.

Intermediate in form between A. Oreas and A. Hügeli, Pfr., this shell was, in the 'Conchologia Iconica,' confounded with $A$. Perrotteti, Pfr., which proved to be a more elongated form, of which A, Nilagirica, B., fig. 87 of the same plate, is a lengthened variety. Pfeiffer cites fig. 102, with a mark of doubt, under A. Perrotteti, in the third vol. of his Manual.

The number of Nilgherry species of Achatina now amounts to nine, or two less than those described from the Island of Ceylon.

\section{May $1,1860$.}

Note. An Achatina, described (without a name) by Capt. T, Hutton in the 3rd vol. of J.A.S. Caleutta, was found by him between Mhow and Nimuch. It equals $A$. tenuispira in length, and appears to be a distinct species.

L.-On the Nomenclature of the Foraminifera, By W. K. Parker, M. Micr. Soc., and T. R. Jones, F.G.S.

[Continued from $\mathrm{p}, 298$.

19. Spirolina, Ann. Mus, v. p. 244; Hist. An. s. Vert. vii. p. 601. Spirolinites depressa. Ann. Mus. v, p. 245; viii. p. 62, f. 14; Hist. An. s. Vert. vii, p. 602, No. 1. "Fossil; Grignon."

This is a Peneroplis planatus, F. \& M. sp. The right-hand figure is nearly orbicular, and may represent a Peneroplis in its Dendritine condition; the other is more complanate, with outspread chambers.

20. Spirolinites cylindracea. Ann. Mus. v. p. 245. No. 2; viii. pl. 62, f. 15; Tabl. Enc. Méth. pl. 465. f. 7 a-c, and pl 466. f. $2 a, b$; Hist. An. s. Vert, vii. p. 603, No. 2, "Fossil; Grignon."

Endless modifications of the constricted and crozier-like forms*

* Spirolina stenostoma, Deshayes (in Lyell's 'Principles,' pl.4.f. 15-18, and 'Manual,' 5th edit. fig. 237), is one of these lituate varieties, narrow and somewhat flattened. 


\section{$2 \mathrm{BHL}$ Biodiversity Heritage Library}

Benson, W. H. 1860. "XLIX.-On new land-shells from Darjiling, with a series of new Indian species of Achatina." The Annals and magazine of natural history; zoology, botany, and geology 5, 460-466.

View This Item Online: https://www.biodiversitylibrary.org/item/19558

Permalink: https://www.biodiversitylibrary.org/partpdf/39868

\section{Holding Institution}

Natural History Museum Library, London

\section{Sponsored by}

Natural History Museum Library, London

\section{Copyright \& Reuse}

Copyright Status: Public domain. The BHL considers that this work is no longer under copyright protection.

This document was created from content at the Biodiversity Heritage Library, the world's largest open access digital library for biodiversity literature and archives. Visit BHL at https://www.biodiversitylibrary.org. 